\title{
Research on the Legal System Construction of China's Informal Financial Market Access
}

\author{
Xiaozhi HU \\ Guanghua Law School \\ Zhejiang University \\ Hangzhou China \\ 305949321@qq.com
}

\begin{abstract}
China's current legal norms of informal finance is lacking in system, in which the absence of the market access system is one of the distinctive features. To construct China's informal financial market access legal system, and tackle the existing problems in the informal financial market such as the basic legal gaps, the lack of regulatory basis and the chaos of the market order, this paper discussed approaches of reforming informal finance regulation and existing key regulation mode of suppressing informal finance, and systematically constructing the informal financial market access system. The informal financial market has various entities, so the access system should be designed by distinguishing the market entity types so as to match the risk level, the external effect and the social influence degree of different subjects. On the basis of the standards of operation, development degree and stakeholder, this paper points out that the market access should be composed of examination and approval system and filing system, and it should set up exemption clauses for approval and filing.
\end{abstract}

Keywords-informal financial market; market access; operating standard; examination and approval system; filing system

\section{AN ANALYSIS OF THE CHARACTERISTICS OF CHINA'S INFORMAL FINANCE}

The concept of "informal finance" needs to be made clear before we propose to construct the informal financial market access legal system. On the basis of the summarization and analysis of the existing research results [1]-[3], the development history and the main features of informal finance in China, this paper defines informal finance as an activity with "financial functions" (1) which has not yet been "institutionalized" (2).

China's informal finance has the following characteristics. First, informal financial entities and financing modes have diversity. From the perspective of the legal nature of the subject, informal financial entities can be natural persons, legal persons or other organizations. From the perspective of

\footnotetext{
The extension of "financial function" includes: the payment intermediary, the credit intermediary, the credit creation.

(2) The standards of "institutionalization" include: "ex ante" entity access system, "in-the-middle" supervision and management system, "ex post" entity exit system and accountability mechanism. The judgment whether some social activities are institutionalized or not is not a simple qualitative, but the measure of "quantity" with fuzzy boundaries.
}

the legal nature of the behavior, informal finance involves equity financing, debt financing, partnership share financing, trust financing, guarantee behavior, etc.

Second, informal finance is endogenous. Informal finance enjoys a unique competitive advantage and is a natural product of social development. Traditional informal financial activities are based on kinship, business relationship and geographical relationship. The relatively sufficient information possessed by the participants makes it possible to bring such problems as low transaction costs, moral hazard and adverse selection well under control.

Third, informal finance is highly market-oriented. China's long-standing policy of financial repression has undermined the level of the formal financial marketization. In contrast, the lack of regulation of informal finance instead has a higher degree of marketization.

For many years, informal finance has failed to attract the attention of the legislators with a positive image. The main purpose of formulating a large number of administrative rules and regulations as well as judicial interpretations is to guarantee the formal financial system's possession and monopoly of the financial resources, to restrict or even ban the diversion of financial resources by informal finance. When the starting point of the legal system is to limit the freedom of informal financial entities, then this provision is the violation of financing freedom instead of the protection of financial market entities [4].

Therefore, the formulation of these normative documents fails to take the characteristics of informal finance into consideration and is lacking in the positive system settings in accordance with the characteristics of informal finance, which results in the problem that many systems are divorced from reality.

The legal system construction of informal financial market access shows the positive attitude of legislation to informal finance. Moreover, based on the specific design of the market classification access system, it can effectively respond to the characteristics of informal finance, reducing barriers to applicable laws. 


\section{Distinguishing THE TYPES OF MARKET ENTITIES AND CONSTRUCTING ACCESS SYSTEM}

The system design of informal financial market access should follow the concept of market-oriented regulation. The concept means: Firstly, the informal financial market on the whole is the object of regulation; secondly, the rationality of informal financial market should be recognized and its social investment and financing needs should be respected; thirdly, market mechanism should play a leading role in informal financial activities. Under the guidance of the concept of market-oriented regulation, we should systematically construct the informal financial market access legal system on the basis of reality, with emphasis on the correlation, coordination and feasibility of the system.

The informal finance entity has the features of complexity, diversity and openness, which determines that we need to follow multiple standards to distinguish the types of market entities when constructing the informal financial market. Below we will classify the types of informal financial market entities from the three dimensions of "operation", "development degree" and "stakeholder".

\section{A. Classification of the Entity from the Perspective of "Operation"}

An operating informal financial entity should have the following characteristics. First it participates actively in informal financial activities with nonspecific and multiple counterparties. Second, its participation in informal financial activities aims at obtaining profits. Third, by employing a relatively fixed business model, it specializes in informal financial activities without other main business.

In the informal financial market, there are three unequal relations between operating and non-operating entities. The first is the inequality of professionalism, the second is the different ability to get information and the last is the unequal status of negotiation. The reason for the unequal status of informal financial entities is that the basic law fails to make distinctions between operating informal financial entities and non-operating entities. Only by distinguishing the informal financial entities in accordance with the operating standards can we entitle the two types of entities with different rights and obligations in the design of the legal system in order to guarantee the de facto fair treatment.

In order to classify the informal financial entities in accordance with the operational standard, we first divide the entities into two types, namely, operating entities and non-operating entities. Then operating entities are subdivided into the entities which absorb funds and which don't absorb funds and the division is mainly based on the external effects of the business activities of informal financial entities. Non-operating entities are subdivided into investment entities, production financing entities and living financing entities and the division is based on risk level.

\section{B. Classification of the Entity from the Perspective of "Development Degree"}

The main purpose of the classification of informal financial entities from the perspective of development degree is to analyze and demonstrate the problem of the intensity of regulation and the necessity of regulation for different informal financial entities. As far as development tendency is concerned, informal finance is experiencing the transformation from being unorganized to organize. In short, the more developed the informal financial entities are, the more mature and complex regulation measures provided by the law they will require.

From the perspective of development degree, informal financial entities can be divided into three levels: primary, intermediate and advanced. The informal financial entity in primary level refers to the entity that does not have an organization form and only occasionally participates in informal financial activities. The informal financial entity in intermediate level refers to the entity with credit mutual help as the main purpose. It has certain organization form and has the profiting function as well, such as ROSCA, credit cooperatives, etc. The informal financial entity in advanced level enjoys a special form of organization, such as underground banks, private equity funds. It generally has the characteristics of carrying out business and its behavior of absorbing funds doesn't carry an implicit guarantee from the government. Payment crisis may result in the spread of risk; the absence of law makes it hard to apply judicial relief in case of dispute.

\section{Classification of the Entity from the Perspective of "Stakeholder"}

Research on the classification of the informal financial entity from the perspective of "stakeholder" is to distinguish informal financial entities according to social influence. Comparatively speaking, the informal financial entity with more people involved is more likely to lead to regional and systematic financial crises and to cause mass disturbances. There is more necessity to implement regulation on such entities (such as the early Jishou illegal fund-raising case, the recent Yunnan pan-Asian event, etc.). Market autonomy is more suitable for the informal financial entities with less people involved.

The division of the informal financial entity by the standard of stakeholder is not to admit or deny generally the legitimacy of stakeholder business in accordance with the relevant provisions of the charges of "illegal fund-raising" in the existing criminal law. In this context, the informal financial entity can be classified according to the following standard of stakeholder. The first is the number of transaction objects. At present, based on the relevant provisions of China's Securities Law, we can rank the stakeholders from strong to weak: no specific object, more than 200 specific objects and no more than 200 specific objects. The second is the identity features of financing objects including information access capability, risk tolerance, financial professional skills. The third is the way of publicity of informal financial activities. Different publicity methods may lead to the different number of people involved. Publicity can be either public or 
non-public in which non-public includes both the publicity for specific objects and the publicity for non-specific objects with some kind of qualification (such as qualified investors)

For the informal financial entity with more stakeholders, a comprehensive legal system should be constructed with controlling the risk level as the core so as to complete the transformation from informal finance to formal finance. For the informal financial entity with fewer stakeholders, the intensity of the legal regulation should be weakened with the reduction of its public interest, so as to avoid excessive legal intervention.

\section{SPECIFIC DESIGN OF MARKET CLASSIFICATION ACCESS SYSTEM}

\section{A. Examination and Approval System for Market Access}

1) Applicable objects of examination and approval system

Examination and approval system is the most rigorous entity access system and correspondingly it applies to the informal financial entity which has the highest risk level and the largest social impact. From the perspective of operation, this type of informal financial entity is the operating informal financial entity. From the perspective of stakeholder, it is the informal financial entity with many stakeholders involved. From the perspective of development degree, the informal financial entity, to which the examination and approval system is applicable, is an advanced form of informal finance.

The informal financial entity can also be divided from the perspective of business mode, among which there are money brokers, underground banks and some other informal financial entities such as investment consulting firms, wealth management companies, Internet lending platform (except for pure information intermediaries). Examination and approval system should be applicable to the market access of the above informal financial entities.

\section{2) Procedures and standards of examination and approval} system

Due to such factors as the differences in the level of economic development in different regions of China and the differences in informal financial transaction habits, when the examination and approval system for market access of informal financial entities is formulated, the central government should first introduce basic legislation and then empower local governments to formulate implementation rules. The contents of the basic legislation include the examining and approving authorities, the categories of qualification requirements of entity access, the implementation rules formulated by local governments on the basis of the basic legislation by the central government and the specified qualification requirements for the informal financial entity within the jurisdiction area. The examination and approval system for the informal financial entity access should formulate and declare the specific requirements for entity qualifications. When the entity that applies to enter informal financial market satisfies the qualification requirements specified in the relevant specifications, the application and the supporting materials will be submitted to the examination and approval authority and the authority will check the applicant's qualifications and authenticity of the materials and make a decision of "approval" or "disapproval” strictly based on the review results. The core materials that the applicant should provide include: a) The application about the type of the informal financial entity to be established; b) shareholder agreement; c) articles of corporation; d) capital verification report; e) legal opinion letter; f) market access qualification reports of major shareholders and senior management.

Informal financial entities that the examination and approval system is applicable to are similar in terms of risk level and external effect, and they have some different characteristics as well which include service product design, operation and management mode, market competition, degree of information asymmetry, the professionalism of personnel, etc. The design of examination and approval system should treat the entities differently according to the characteristics. Under the premise of maintaining the bottom line of risk prevention, the design of examination and approval system should try to meet the institutional demands of different types of informal financial entities.

\section{3) Legal liability}

The examination and approval system of informal financial entity access will bring high cost to the applicants, and it also prevents a number of potential informal financial entities from entering the market. In other words, the implementation of the approval system will face greater resistance. Therefore, in order to ensure the implementation of the examination and approval system of entity access, there is a need to establish the relevant legal liability.

The legal liability for the destruction of the examination and approval system should be divided into administrative responsibility and criminal responsibility. In terms of administrative responsibility, it comes in two forms: "money penalty" (administrative fines) and "qualification penalty" (the punishment on business qualifications such as suspension of business and revocation of business licenses) and it aims at establishing penalties that match the illegal motives of the offenders. Criminal responsibility, an instrumental use of criminal penalty, is applicable to the illegal acts which cause serious adverse consequences to the market order.

Before the application is approved and the organization of informal financial entity is legally established, the bearer of legal liability should be the natural person of the applicant. After the approval, the bearer of legal liability should be the informal financial entity with a certain form of organization.

Informal financial market has strong regional characteristics and therefore, considering such factors as supervision efficiency and the effect of law enforcement, the local administrative organs should be endowed with the power of administrative punishment,

The provincial people's congresses can legislate to empower the Financial Office or the Monetary Authority under provincial governments to specialize in investigating the administrative responsibility for violating the examination and approval system. Meanwhile, the institutional levels responsible for implementing administrative punishment should be limited in order to avoid abuse of power brought about by the excessive decentralization of power. 


\section{B. Filing System of Market Access}

\section{1) Applicable objects of filing system}

Filing system is designed to address the barriers to information access in informal financial regulation. Under the market-oriented regulation, filling system only requires supervisors to provide regulatory information instead of setting additional obstacles for informal financial entities when they participate in market activities. Filing system is a kind of system design with less market intervention.

From the perspective of operation, filing system is applicable to informal financial entities that are operating entities and do not absorb public funds. From the perspective of stakeholder, filing system is applicable to informal financial entities whose transaction objects are unspecified majority or more than 200 specific objects. From the perspective of development pattern, filling system generally applies to informal financial entities in the primary and intermediate stage of development.

On the basis of business mode, informal financial entities can be divided into ROSCA, enterprise fund raising, financing information intermediary, credit cooperatives, professional lenders, etc. Filing system is also applicable to the market access of these informal financial entities. There is a need for the implementation of supervision over these entities in terms of systemic risk prevention, but it is not necessary to exercise additional control and hence filing system of entity access is adopted.

\section{2) Procedures and standards of filing system}

The key to access filing system is obtaining basic information required for regulation, rather than preventing the relevant entities from entering informal financial market and therefore, there is no need for pre-filing system.

The establishment of informal financial entities generally experiences the planning stage, the stage of performing procedures and the stage of carrying out business. The responsibility of reporting information given by filing system should be fulfilled before informal financial business is carried out. The filing person, the main establisher of the informal financial entity or the informal financial entity after the establishment, submits filing materials to local financial management departments.

In order to achieve the basic goal of monitoring market risk level, the materials submitted by informal financial entities under the filing system are different in accordance with main business model and business scope. The materials submitted mainly include the following information: First, business model risk level; second, the scope of business objects; three, their own risk-bearing capacity; four, their own business level and risk control level. In consideration of regional differences, it is recommended that the central government first legislates and then empowers provincial state organs to formulate specific rules.

\section{3) Legal liability}

The legal liability for access filing system mainly lies in administrative responsibility. The access filing system of informal financial entity is a mandatory information report and the relevant entity should bear administrative responsibility for such acts as false information or delay in the implementation of the filing formalities. However, the false fulfillment of the filling obligation or delay in the fulfillment cannot bring about the loss of the entity's qualification for informal financial market, so administrative responsibility should resort to the means of "money penalty".

\section{Exemption Clause for Market Access}

In terms of objective, the economy is undoubtedly the ultimate cause for the existence of the exemption system. Economy here means that the necessity and feasibility of regulation are lost from the perspective of the society as a whole when regulatory costs are greater than regulatory benefits, and the exemption of access restrictions should be adopted.

\section{1) Applicable objects of exemption clause}

Exempt access restrictions, access filing system and access approval system show the characteristic of gradual strengthening government intervention, namely, the characteristic of gradual weakening market self-determination. The basis of strengthening government intervention includes the existence of market failure and the requirement of public interest. The discussion about the exemption of market access restrictions of informal financial entities from these two aspects can determine the applicable objects of exemption clause.

In terms of market failure, it is an inevitable phenomenon in the informal financial market with incomplete information and insufficient competition. This phenomenon cannot be mitigated by restricting the access of the informal financial entities with little influence and with the nature of mutual aid to the market. On the contrary, when small-scaled informal financial entities with a low degree of organization that do not absorb public funds enter the market, they will help alleviate the problem of market failure by enhancing the level of market competition and inhibiting monopoly. From the perspective of public interest, as long as the specific informal financial entities have limited influence on the market order and limited risk externalities of, there is no need to limit their access to the informal financial market in the name of public interest.

Therefore, according to the above standards of entity types, the objects to which access restriction exemption applies should be the non-operating informal financial entities in the primary stage of development with a small number of specific transaction objects. As far as the informal financial market is concerned, the function of the government is to guide, to lead rather than to push forward. In fact, only the organized informal finance, in particular, informal finance with institutions, need to be standardized more [5].

\section{2) Standard for the application of exemptions}

The construction principle of the exemption system is not unique. With reference to the legislative experience of the US private placement system, the exemption system under the guidance of multiply principles can be set up on the basis of satisfying the market's basic requirements for security, order and fairness.

The judgment standard for the exemption system of private placement in the United States (a major component of 
informal finance) include: Information access standard, insider standard, professional knowledge and experience standard, risk-bearing capacity standard and qualified investor qualification standard [6]-[8].

In contrast to the United States, China's informal financial entity access system requires more aggressive government intervention, which is a waiver of the approval and filing systems, and requires more rigorous applicable standards. At present, the primary standards should include all the following three conditions: specific trading objects, the limited number of trading objects, and the non-operating characteristics of the behavior.

\section{3) Legal liability}

The exemption clause for access restrictions is designed to avoid excessive intervention in the market and therefore does not require the informal financial entity to which the system is applicable to self-certify that in advance. The establishment of exempt liability should be combined with the legal responsibility of access approval system and access filing system. That is to say, the informal financial entity to which the exemption system is not applicable should bear the corresponding legal liability in accordance with its circumvention of the applicable access system. However, in order to ensure the smooth and stable operation of the informal financial market, when the relevant entities carry out informal financial activities without the screening of the access system, the legal relationship they participate in will not necessarily be removed or invalidated. The right to terminate or modify the contract is reserved for their counterparties.

\section{CONCLUSION}

According to the characteristics of China's informal finance, the legal system of China's informal financial market access should consider the distinction between the main market entities and be constructed based on the specific types. Therefor this paper suggests that certain legal system could be designed according to the difference of standards of operation, development degree and stakeholder between different types of informal financial market entities. This legal system of informal financial market access including the examination and approval system, filing system and exemption clauses of market access, which can solve the problems of the absence of the market access system, and maintain market order and serve economic development.

\section{REFERENCES}

[1] Jinkang GAO, Qingli TANG, "Standardized Legal Regulations in China’s Informal Finance”, Beijing: Law Press, 2012, p. 30. (In Chinese)

[2] Youhuan LI: Strengthen the Supervision of the Development of Informal Finance, China Finance, March 2012, p. 76. (In Chinese)

[3] Xuchao JIANG, Changfeng DING, “Analysis of Informal Finance Theory: Category, Comparison and Institutional Change”, Journal of Financial Research, August 2004, pp.100-111. (In Chinese)

[4] Shuqing ZHANG, "Reconstruction of legal value system of private lending”, Shanghai Finance, February 2009, p. 71. (In Chinese)

[5] Rongen HU, "Analysis of Highly Cited Papers in Informal Finance Research”, Tribune of Political Science and Law, March 2014, pp.72-81. (In Chinese)

[6] Xujuan ZHANG, “A Study on the Legal System of Private Placement of Securities in China”, Doctoral Dissertation of China University of Political Science and Law, 2005, p. 55. (In Chinese)

[7] Li GUO, "A Study on the Legal System of Private Placement of Securities in USA”, Beijing: Beijing University Press, 2004, pp.55-91. (In Chinese)

[8] Qinghua LIANG, “The Evolvement and Enlightenment of American Private Registration Exemption System”, Studies in Law and Business, September 2013, pp.144-152. (In Chinese) 